\title{
Pengaruh Bencana Alam terhadap Spiritualitas Jemaat (Studi Kasus Jemaat Gereja Bala Keselamatan Korps Jono Oge)
}

\section{The Effect of Natural Disasters on Church Spirituality (Case Study of The Salavtion Army Congregation of Jono Oge Corps)}

\author{
Royke Lepa ${ }^{1 *}$ \\ 1) STT Bala Keselamatan Palu \\ *Penulis Korespondensi: roykelepa0@gmail.com
}

Received: 1806 2020/ Accepted: 0705 2021/Published: 01062021

\begin{abstract}
Abstrak
Pasca bencana alam yang menimpa Provinsi Sulawesi Tengah membawa dampak yang besar bagi kehidupan masyarakat secara khusus spiritualitas atau kehidupan iman jemaat yang berada di Gereja Bala Keselamatan Korps Jono Oge. Penelitian ini bertujuan untuk mengetahui apakah bencana alam berpengaruh terhadap spiritualitas jemaat. Untuk mendapatkan hasil digunakan metode kuantitatif untuk mengetahui pendapat responden. Selanjutnya data yang terkumpul diolah dengan menggunakan analisis frekuensi. Hasil penelitian menunjukkan bahwa bencana alam yang terjadi pada 28 September 2018 membawa dampak yang baik bagi kehidupan spiritualitas jemaat. Hal tersebut ditunjukkan bahwa jemaat mempunyai pandangan yang benar terhadap bencana. Variabel-variabel spiritualitas menunjukkan bahwa bencana berpengaruh terhadap iman yang bertumbuh, kehidupan doa dan membaca Firman Tuhan, kesetiaan dalam beribadah dan melayani.
\end{abstract}

Kata-kata Kunci: Bencana, Bencana Alam, Spiritualitas, Jemaat.

\begin{abstract}
After natural disasters that befell Central Sulawesi brought a massive impact on people's lives, especially in spirituality or the life of faith of the congregation in Jonooge Corps of The Salvation Army. This research aimed to find out whether natural disasters affected the spirituality of the congregation. Furthermore, to obtain information from this, quantitative methods were used to determine respondents' opinions. Furthermore, the data collection was processed by using frequency analysis. The results showed that the natural disasters that occurred on 28 September 2018 had brought good impact on the church's spiritual life. The congregation proved this had a positive perspective on disasters, and spirituality variables showed that disasters
\end{abstract}


affected growing faith, praying for life, reading God's scripture, and faithfulness in worship and service.

Keywords: Church, Disaster, Natural Disaster, Spirituality.

\section{PENDAHULUAN}

Pada tanggal 28 September 2018 masyarakat Sulawesi Tengah secara khusus yang berada di wilayah Kabupaten Sigi, Kabupaten Donggala dan Kota Palu merasakan bencana alam berupa gempa bumi, likuifaksi dan tsunami. Ketiga jenis bencana ini terjadi dalam waktu yang sama secara hampir bersamaan. Gempa bumi tektonik yang terjadi pada hari Jumat, 28 September 2018, jam 17:02:44 WIB dengan M 7.7, lokasi 0.18 LS dan 119.85 BT dan jarak 26 km dari Utara Donggala, Sulawesi Tengah, dengan kedalaman $10 \mathrm{~km}$. Gempa bumi ini mengakibatkan terjadinya Tsunami di pesisir pantai Talise dan Donggala, serta likuifaksi di Perumahan Balaroa, Perumahan Petobo, desa Sibalaya dan Desa Jono Oge. Bencana ini mengakibatkan korban 2101 meninggal, 1373 hilang dan 443 korban luka, dan 221.450 mengungsi, (Wareza, 2018).

Bencana ini berdampak pada berbagai lini kehidupan masyarakat baik secara ekonomi, budaya, sosial dan secara khusus kehidupan spiritual. Jemaat Gereja Bala Keselamatan Korps Jono Oge juga merasakan dampak-dampak tersebut karena mereka berada pada wilayah yang terkena likuifaksi. Kehidupan rohani juga berdampak karena kegiatan gereja dan kerohanian terhenti begitu lama. Gedung gereja yang baru sebagai tanda dari hadirnya kekristenan dan menjadi kebanggaan, rusak berat dan akhirnya dirobohkan.

Dalam kondisi yang berdampak besar ini, terdapat dua sikap dari jemaat dalam menanggapi dampak bencana tersebut. Ada yang sangat berat menerima dan ada yang terbuka untuk menerima dampak dari bencana alam tersebut. Jemaat sulit untuk menerima dampak tersebut karena menghancurkan sendi-sendi kehidupan ekonomi mereka seperti rusaknya hasil pertanian, perkebunan dan usaha. Sikap tidak menerima akibat bencana alam ini semakin kuat karena melihat Gedung Gereja yang berusaha dibangun selama beberapa tahun, rusak total hanya dalam beberapa menit dan tidak dapat digunakan sama sekali. Artinya, sikap tidak menerima disebabkan karena dampak secara ekonomi dan spiritual. Di sisi lain ada pihak yang menerima dampak dari bencana alam karena mereka memandang bencana alam terjadi karena sesuai dengan izin Tuhan.

Tetapi yang menarik adalah, tanda-tanda kehidupan rohani atau spiritual jemaat terlihat saat situasi itu terjadi. Hal itu terkait sikap yang bergantung pada Tuhan, 
kehidupan doa yang meningkat, kerinduan untuk membaca firman Tuhan, kerinduan untuk beribadah meskipun di tempat yang terbuka dan sikap yang mau saling berbagi kasih di tengah-tengah keterpurukan dan terbatas.

Penulisan artikel ini bertujuan untuk mengetahui pengaruh bencana alam terhadap kehidupan kerohanian atau spiritualitas jemaat pasca mengalami bencana alam, secara khusus jemaat Gereja Bala Keselamatan Korps Jono Oge, Kecamatan Biromaru, Kabupaten Sigi, Provinsi Sulawesi Tengah.

\section{TEORI}

\section{Bencana Alam dan Spiritualitas}

Secara etimologi bencana berasal dari kata disaster. Kata berasal dari bahasa yunani kuno yaitu 'dus' yang berarti buruk dan 'aster' yang berarti 'bintang'. Kata ini mengacu kepada fenomena astronomi yang berkonotasi pada sesuatu yang buruk. Kata itu diserap menjadi bahasa Perancis 'desastre' yang berarti kerusakan, terutama yang disebabkan oleh peristiwa alam. Artinya, keseluruhan peristiwa alami yang bersifat destruktif, misalnya gempa bumi, banjir, tanah longsor, tsunami, badai salju, kekeringan, seringkali diterima begitu saja sebagai disaster atau bencana, (Indiyanto, 2012, p. 7).

Bencana merupakan segala peristiwa yang bersifat merusak, merugikan, mengganggu serta mengancam kehidupan manusia. Bencana mempunyai arti yang cukup luas untuk segala hal yang menjadi ancaman bagi manusia. Bencana memiliki 3 (tiga) aspek, yaitu: (1) terjadinya peristiwa atau gangguan yang mengancam dan merusak, (2) peristiwa atau gangguan tersebut mengancam kehidupan, penghidupan, dan fungsi dari masyarakat, dan (3) ancaman tersebut mengakibatkan korban dan melampaui kemampuan masyarakat untuk mengatasi dengan sumber daya mereka (Isa, 2016, p. 150).

Menurut Sudibyakto bencana alam adalah (2011, p. 1):

Suatu peristiwa atau rangkaian kejadian yang mengakibatkan korban penderitaan manusia, kerugian harta benda, kerusakan lingkungan, sarana dan prasarana serta dapat menimbulkan gangguan terhadap tata kehidupan dan penghidupan masyarakat.

Sedangkan menurut Undang-undang Nomor 24 Tahun 2007 tentang Penanggulangan Bencana, mengatakan bencana adalah (Badan Nasional Penanggulangan Bencana, n.d.):

Peristiwa atau rangkaian peristiwa yang mengancam dan mengganggu kehidupan dan penghidupan masyarakat yang disebabkan, baik oleh faktor alam dan/atau faktor non alam maupun faktor manusia sehingga mengakibatkan timbulnya korban jiwa manusia, kerusakan lingkungan, kerugian harta benda, dan dampak psikologis. 
Bencana alam dapat didefinisikan peristiwa alam yang terjadi secara alamiah tanpa campur tangan manusia peristiwa yang mendatangkan kerugian dan mengganggu kehidupan umat manusia. Menurut Dyah Anggraini, bencana alam adalah: bencana yang diakibatkan oleh peristiwa atau serangkaian peristiwa yang disebabkan oleh alam antara lain berupa gempa bumi, tsunami, gunung meletus, banjir, kekeringan, angin topan, dan tanah longsor (Anggraini, 2019, p. 13). Dedi Hermon berpendapat bencana alam merupakan "bencana yang terjadi akibat terganggunya keseimbangan komponen-komponen alam tanpa campur tangan manusia" (Hermon, 2018, p. 2). Bencana alam memiliki beberapa jenis yaitu banjir, kebakaran hutan, gempa, tsunami, gunung meletus, angin puting beliung, tanah longsor, pemanasan global, dan kekeringan (Khambali, 2017, p. 4-11). Bencana alam menimbulkan banyak sekali dampak negatif bagi kehidupan masyarakat, di antaranya adalah timbul korban jiwa yang tidak sedikit, hilangnya harta benda, kerusakan lingkungan, dan terganggunya fungsi psikologis para korban bencana alam (Utomo, 2016, p. 47). Bencana alam juga dapat memengaruhi kehidupan spiritual masyarakat yang dilanda oleh bencana tersebut.

Bencana alam yang terjadi dipengaruhi oleh banyak faktor. Faktor-faktor yang memengaruhi suatu daerah menjadi rawan terhadap bencana adalah 2 (dua) hal berikut yaitu: (1) kondisi alam meliputi: posisi geografis, topografi, kondisi geologi, seismisitas (kegempaan), dan lain-lainnya serta (2) kondisi sosial meliputi: struktur penduduk, kerentanan penduduk terhadap bencana, jaringan infrastruktur serta pemanfaatan wilayah/daerah untuk sesuatu (land-use). Besar kecilnya risiko suatu bencana dipengaruhi oleh bahaya bencana tersebut serta kerentanan terhadap bencananya (Martini, 2011, p. 97).

\section{Bencana 28 September 2018}

Pada tanggal 28 September 2018, di Provinsi Sulawesi Tengah terjadi bencana alam yaitu gempa bumi, likuifaksi dan tsunami.

\section{Gempa Bumi 28 September 2018}

Indonesia dikenal sebagai salah satu negara yang rawan terkena bencana alam. Hal ini disebabkan Indonesia terletak di antara pertemuan tiga lempeng tektonik yang bertumbukan yaitu Lempeng Indo-Australia, Lempeng Eurasia, dan Lempeng Pasifik, (Utomo, 2016, p. 49). Wilayah Sulawesi Tengah tersebut dikenal tempat bertemunya tiga lempeng tektonik utama dunia yaitu Lempeng Indo-Australia, Lempeng Pasifik, dan Lempeng Eurasia. Akibatnya, wilayah ini rawan akan bencana alam terutama yang diakibatkan oleh pergerakan lempeng-lempeng tersebut, yang mendorong pergerakan Sesar Geser Palu Koro. Hal ini pula yang menyebabkan gempa bumi berkekuatan 7,4 Mw yang meluluhlantakan wilayah pesisir Teluk Palu, yaitu Kota Palu, Kabupaten Sigi dan Kabupaten Donggala pada 28 September 2018, (Badan Geologi, 2018, p. 4). 
Gempa dahsyat ini memicu likuifaksi dan tsunami. Beberapa wilayah yang mengalami likuifaksi adalah Kelurahan Petobo dan kelurahan Balaroa di Kota Palu, desa Sibalaya dan Jono Oge di Kabupaten Sigi. Balaroa terletak di tengah-tengah Sesar Palu-Koro. Saat terjadinya likuifaksi, terjadi kenaikan dan penurunan muka tanah. Beberapa bagian amblas 5 meter, dan beberapa bagian naik sampai 2 meter. Di Petobo, ratusan rumah tertimbun lumpur setinggi 3-5 meter. Setelah gempa, tanah di daerah itu dengan lekas berubah jadi lumpur yang dengan segera menyeret bangunan-bangunan di atasnya. Di Balaroa, rumah amblas, bagai terisap ke dalam tanah. Di desa Jono Oge juga terjadi pergeseran tanah yang mengakibatkan banyak bangunan hancur dan korban Jiwa (Badan Geologi, 2018, p. 165).

\section{Likuifaksi 28 September 2018}

Bencana likuifaksi yang terjadi di empat wilayah di Sulawesi Tengah menarik perhatian dari berbagai belahan dunia yang membuat para ilmuwan berlomba-lomba menjelaskan apa itu bencana alam likuifaksi. Likuifaksi sendiri adalah sebuah fenomena yang terjadi saat massa tanah yang kehilangan sebagian besar tahanan geser akibat adanya suatu faktor pembebanan maupun getaran yang bersifat mendadak sehingga menyebabkan bergerak seperti material cair (Prayudi, 2019, p. 165). Peneliti geologi telah mengemukakan apa yang dimaksud dengan bencana alam likuifaksi (Badan Geologi, 2018, p. 162):

Likuifaksi merupakan gejala peluluhan pasir lepas yang bercampur dengan air akibat goncangan gempa di mana gaya pemicu melebihi gaya yang dimiliki litologi setempat dalam menahan guncangan. Hal ini bisa menyebabkan beberapa kejadian seperti penurunan cepat (quick settlement), pondasi bangunan menjadi miring (tilting) atau penurunan sebagian (differential settlement), dan mengeringnya air sumur yang tergantikan oleh material nonkohesif.

Penyebab dari bencana likuifaksi ini menjadi pertanyaan masyarakat dan juga berbagai pihak yang memberi perhatian atas kejadian ini. Sutopo memberikan penjelasan tentang hal ini sebagai beriku (https://bnpb.go.id/potensi-bencana):

Ada dua teori yang memungkinkan fenomena langka ini terjadi. Pertama, guncangan gempa yang menyebabkan lapisan-lapisan tanah bawah yang awalnya padat, kemudian bercampur dengan air di bawah tanah, kemudian memuncratkan lumpur. Kekuatan (tanah)-nya berkurang, yang akhirnya menyebabkan bangunan yang ada di atasnya, pasti hancur diguncang gempa dengan posisi tanah di bawahnya gembur, amplifikasinya semakin besar, sehingga patah strukturnya. Teori kedua, adalah akibat keberadaan lumpur purba yang terjebak di bawah permukaan tanah. Ketika gempa terjadi dan timbul retakan, lumpur itu keluar. 
Dari teori yang dijelaskan oleh Sutopo maka dapat diketahui Likuifaksi di Palu merupakan bencana alam yang terjadi akibat kekuatan tanah berkurang akibat gempa dan juga dapat disebabkan oleh keberadaan lumpur purba yang ada di dalam bawah tanah.

Dampak dari bencana likufaksi ini, beberapa bagian permukaan tanah amblas 5 meter, dan beberapa bagian naik sampai 2 meter. Di Petobo, ratusan rumah tertimbun lumpur setinggi 3-5 meter. Setelah gempa, tanah di daerah itu dengan lekas berubah jadi lumpur yang dengan segera menyeret bangunan-bangunan di atasnya. Di Balaroa, rumah amblas, bagai terisap ke dalam tanah. Di Jono Oge masyarakat menyebutnya sebagai desa yang hilang dikarenakan oleh hilangnya rumah, jalan, perkebunan tertelan lumpur dan terseret begitu jauhnya (Badan Geologi, 2018, p. 161-174).

\section{Tsunami 28 September 2018}

Penyebab tsunami 28 September 2018 di kota Palu dan sekitarnya adalah sesar mendatar yang memanjang mulai dari Kecamatan Kulawi di selatan, melintasi Kota Palu hingga Desa Tambu di utara, tiba-tiba bergerak dan menyebabkan anomali tsunami. Gelombang tsunami melanda Kota Palu di dasar Teluk Palu dengan tinggi rendaman maksimum $6 \mathrm{~m}$. Beberapa saksi mata menyaksikan fenomena gelombang tsunami yang tidak lazim. Berdasarkan observasi para peneliti, akibat dari tsunami adalah tsunami menerjang pantai, menghantam pemukiman hingga gedung-gedung dan fasilitas umum. Data menyebutkan bahwa titik tertinggi tsunami tercatat 11,3 meter, terjadi di Desa Tondo, Palu Timur, Kota Palu. Sedangkan titik terendah tsunami tercatat 2,2 meter, terjadi di Desa Mapaga, Kabupaten Donggala. Banyak rumah rusak, infrastruktur hancur, bahkan sampai merenggut nyawa yang hingga sekarang belum ditemukan (Badan Geologi, 2018, p. 133-142).

\section{Spiritualitas Jemaat}

Kata "spiritulitas" atau "kerohanian" berasal dari kata "spiritual" (Yun. Pneumatikos), berakar kata dari "spirit" (pneuma). Spirit (pneuma) dapat berarti roh (dari Allah); jiwa, kehidupan yang batin, diri pribadi; watak; roh atau kuasa (sering dari roh jahat); hidup; angin; nafas, (Newman Jr, 1994, p. 136). Spiritual merupakan hal yang penting atau prinsip dimana tubuh dihidupkan; suatu roh, baik roh manusia atau malaikat. Spiritual (Pneumatikos) berarti rohani; orang yang rohani, hal yang rohani, karunia rohani, atau hal yang berkenaan dengan roh manusia, jiwa atau pikiran, sebagai bagian dari tubuh manusia. Jadi spiritualitas dapat diartikan keadaan kerohanian seseorang, dalam hal kerohanian yang dimaksud adalah kerohanian Kristen. Spritualitas berarti berbicara tentang kerohanian sejati. Dalam kerohanian ada afeksi yang membawa kita dekat kepada Tuhan (McDermott, 2001, p. 35). Spiritualitas juga merupakan nilai-nilai yang mendasari, mendorong, menginspirasi atau mengilhami, menjiwai, mengontrol atau mengendalikan, memandu, mengarahkan hidup dan semua aktivitas atau yang dikerjakan (Bawamenewi, 2020, p. 61). 
Jadi spiritualias dalam pengertian pertumbuhan rohani dapat diartikan segala sesuatu yang dapat dilakukan untuk membuat seseorang memiliki hubungan secara pribadi dengan Tuhan, dalam persekutuan dengan Yesus, yang dikerjakan melalui karya Roh Kudus yang melahir barukan seseorang. Arthur W. Pink, sebagaimana di kutip oleh Stevry Lumintang mengatakan: "Karena pertumbuhan rohani mengharuskan dengan pasti adanya kehidupan rohani. Hanya orang yang yang telah mengalami kelahiran barulah yang mengalami pembentukan rohani atau pertumbuhan rohani" (Lumintang, 2006, p.231). Sedangkan spiritualitas sejati, kuncinya lebih terletak pada relasi dengan Allah daripada pengetahuan tentang Allah, (Nego, 2019, p. 26).

Kehidupan spiritualitas jemaat dalam penelitian ini dapat dilihat dalam beberapa aspek seperti pemahaman tentang bencana, iman yang bertumbuh setiapa hari, kesetian berdoa, kesetiaan membaca Alkitab, ketekunan beribadah, dan ketekunan.

\section{METODE}

Penelitian ini dilakukan di desa Jono Oge, Kecamatan Biromaru, Kabupaten Sigi, Provinsi Sulawesi Tengah, secara khusus pada jemaat Gereja bala Keselamatan Korps Jono Oge pada tanggal 1 sampai 7 Mei 2019. Data yang digunakan adalah data primer yaitu data dikumpulkan langsung pada objek penelitian. Sedangkan responden dalam penelitian ini berjumlah 53 responden.

Metode penelitian adalah penelitian kuantitatif (Serli dan Wijaya, 2020, p. 23; Sareong dan Supartini, 2020, p. 36). Pengolahan data dilakukan dengan menggunakan analisis frekuensi dengan tujuan untuk mencari tahu pendapat dari para responden tentang variabel yang berhubungan dengan Bencana Alam dan Spiritualitas. Variabel yang digunakan adalah bencana alam, kehidupan doa, membaca Alkitab, beribadah, melayani, mengasihi, iman yang bertumbuh.

\section{HASIL DAN PEMBAHASAN}

Berdasarkan varaibel-variabel yang yang diteliti, diperoleh data sebagai berikut:

Tabel 1. Tuhan Mengizinkan Bencana Alam ini Terjadi

Tuhan mengizinkan bencana alam ini terjadi.

\begin{tabular}{|ll|r|r|r|r|}
\hline & & & & \multicolumn{1}{c|}{$\begin{array}{c}\text { Cumulative } \\
\text { Percent }\end{array}$} \\
\hline Valid & Sangat Tidak Setuju & 5 & 9.4 & 9.4 & 9.4 \\
& Ragu-ragu & 2 & 3.8 & 3.8 & 13.2 \\
& Setuju & 25 & 47.2 & 47.2 & 60.4 \\
Sangat Setuju & 21 & 39.6 & 39.6 & 100.0 \\
Total & 53 & 100.0 & 100.0 & \\
\hline
\end{tabular}


Berdasarkan tabel 1 di atas, dari lima puluh tiga responden diperoleh data sebagai berikut: lima orang (9.4\%) menyatakan sangat tidak setuju Tuhan mengizinkan bencana alam ini terjadi. Dua orang (3.8\%) menyatakan ragu-ragu Tuhan mengizinkan bencana alam ini terjadi. Sikap ragu-ragu ini disebabkan karena responden sulit untuk memahami bencana alam terjadi atas izin Tuhan. Dua puluh lima orang (47.2\%) menyatakan setuju Tuhan mengizinkan bencana alam ini terjadi. Dua puluh satu orang (39.6\%) menyatakan sangat setuju Tuhan mengizinkan bencana alam ini terjadi. Sikap jemaat yang setuju dan sangat bencana alam terjadi atas izin Tuhan karena memahami bahwa Tuhan berotoritas penuh atas segala ciptaan-Nya. Karena itu apapun yang Tuhan izinkan terjadi harus siap diterima. Data ini memberikan pemahaman bahwa jemaat Gereja Bala Keselamatan Korps Jono Oge mayoritas meyakini bencana alam yang terjadi karena Tuhan mengizinkan.

Tabel 2. Bencana Alam ini adalah Peringatan dari Tuhan

Bencana alam ini adalah peringatan dari Tuhan

\begin{tabular}{|ll|r|r|r|r|}
\hline & Frequency & Percent & Valid Percent & $\begin{array}{c}\text { Cumulative } \\
\text { Percent }\end{array}$ \\
\hline Valid & Sangat Tidak Setuju & 1 & 1.9 & 1.9 & 1.9 \\
& Tidak Setuju & 2 & 3.8 & 3.8 & 5.7 \\
& Setuju & 16 & 30.2 & 30.2 & 35.8 \\
Sangat Setuju & 34 & 64.2 & 64.2 & 100.0 \\
Total & 53 & 100.0 & 100.0 & \\
\hline
\end{tabular}

Berdasarkan tabel 2 di atas, dari lima puluh tiga responden di peroleh data sebagai berikut: Satu orang (1.9\%) menyatakan sangat tidak setuju bencana alam adalah peringatan dari Tuhan. Dua orang (3.8\%) menyatakan tidak setuju bencana alam adalah peringatan dari Tuhan. Responden yang menyatakan sangat tidak setuju dan tidak setuju bencana alam sebagai peringatan dari Tuhan karena memandang tidak mungkin Tuhan akan memberikan bencana hanya untuk mengingatkan mereka. Tuhan seharusnya menggunakan cara lain untuk mengingatkan umat-Nya. Enam belas orang (30.2\%) menyatakan setuju bencana alam adalah peringatan dari Tuhan. Tiga puluh empat orang (64.2\%) menyatakan sangat setuju bencana alam adalah peringatan dari Tuhan. Responden yang menyatakan sikap setuju dan sangat setuju bencana alam sebagai peringatan dari Tuhan kembali melihat bahwa Tuhan memilih cara tersebut untuk memperingatkan mereka. Data ini memberikan pemahaman bahwa jemaat Gereja Bala Keselamatan Korps Jono Oge mayoritas melihat bencana alam yang terjadi sebagai suatu peringatan dari Tuhan. 
Tabel 3. Bencana Alam yang Terjadi adalah Ujian dan Pencobaan bagi Iman Saya

Bencana alam yang terjadi adalah ujian dan pencobaan bagi iman saya.

\begin{tabular}{|ll|r|r|r|r|}
\hline & & & & \multicolumn{1}{c|}{$\begin{array}{c}\text { Cumulative } \\
\text { Percent }\end{array}$} \\
\hline Valid & Ragu-ragu & 5 & 9.4 & 9.4 & 9.4 \\
& Setuju & 30 & 56.6 & 56.6 & 66.0 \\
& Sangat Setuju & 18 & 34.0 & 34.0 & 100.0 \\
Total & 53 & 100.0 & 100.0 & \\
\hline
\end{tabular}

Berdasarkan tabel 3 di atas, dari lima puluh tiga responden diperoleh data sebagai berikut: lima orang (9.4\%) menyatakan ragu-ragu bencana alam yang terjadi adalah ujian dan pencobaan bagi iman. Sikap ragu-ragu ini disebabkan pemahaman yang sangat sulit untuk menerima bencana alam yang begitu dahsyat dapat menumbuhkan iman. Tiga puluh orang (56.6\%) menyatakan setuju bencana alam yang terjadi adalah ujian dan pencobaan bagi iman. Delapan belas orang (34.0\%) menyatakan sangat setuju bencana alam yang terjadi adalah ujian dan pencobaan bagi iman. Sikap responden ini selaras dengan apa yang mereka lakukan setelah bencana terjadi yaitu mereka semakin tekun untuk beribadah, berdoa dan menyerahkan segala aspek kehidupan kepada Tuhan. Data ini memberikan pemahaman bahwa mayoritas jemaat Gereja Bala Keselamatan Korps Jono Oge mayoritas melihat bencana alam sebagai ujian dan pencobaan bagi iman mereka.

Tabel 4. Bencana Alam Membuat Iman Saya Bertumbuh Setiap Hari

Bencana alam me mbuat iman saya bertumbuh setiap hari.

\begin{tabular}{|ll|r|r|r|r|}
\hline & & & & \multicolumn{2}{c|}{$\begin{array}{c}\text { Cumulative } \\
\text { Percent }\end{array}$} \\
\hline Valid & Sangat Tidak Setuju & 1 & 1.9 & 1.9 & 1.9 \\
& Tidak Setuju & 3 & 5.7 & 5.7 & 7.5 \\
& Ragu-ragu & 3 & 5.7 & 5.7 & 13.2 \\
Setuju & 18 & 34.0 & 34.0 & 47.2 \\
Sangat Setuju & 28 & 52.8 & 52.8 & 100.0 \\
Total & 53 & 100.0 & 100.0 & \\
\hline
\end{tabular}

Berdasarkan tabel 4 di atas, dari lima puluh tiga responden diperoleh data sebagai berikut: satu orang (1.9\%) menyatakan sangat tidak setuju bencana alam membuat iman bertumbuh setiap hari. Tiga orang (5.7\%) menyatakan tidak setuju bencana alam membuat iman bertumbuh setiap hari. Sikap responden yang menyatakan sangat tidak setuju dan tidak setuju ini disebabkan oleh pemahaman bencana berdampak tidak baik yang berhubungan langsung dengan iman mereka yang tidak bertumbuh. Tiga orang (5.7\%) menyatakan ragu-ragu bencana alam membuat iman bertumbuh setiap hari. Sikap ragu-ragu ini disebabkan karena responden sulit untuk membedakan iman mereka bertumbuh atau tidak dalam hidup sehari-hari. Delapan belas orang (34.0) menyatakan setuju bencana alam membuat 
iman bertumbuh setiap hari. Dua puluh delapan orang (52.8\%) menyatakan sangat setuju bencana alam membuat iman bertumbuh setiap hari. Sikap responden yang menyatakan setuju dan sangat setuju dikarenakan menurut mereka bencana dipakai oleh Allah unutk membentuk kehidupan rohani mereka semakin bersandar pada Tuhan. Data ini memberikan pemahaman bahwa mayoritas jemaat Gereja Bala Keselamatan Korps Jono Oge mayoritas melihat bencana alam membuat iman mereka bertumbuh.

Tabel 5. Bencana Alam Membuat Saya Semakin Setia Berdoa

Bencana alam membuat saya semakin setia berdoa.

\begin{tabular}{|ll|r|r|r|r|}
\hline & & & & \multicolumn{1}{c|}{$\begin{array}{c}\text { Cumulative } \\
\text { Percent }\end{array}$} \\
\hline Valid & Tidak Setuju & 1 & 1.9 & 1.9 & 1.9 \\
& Ragu-ragu & 3 & 5.7 & 5.7 & 7.5 \\
& Setuju & 27 & 50.9 & 50.9 & 58.5 \\
Sangat Setuju & 22 & 41.5 & 41.5 & 100.0 \\
& Total & 100.0 & 100.0 & \\
\hline
\end{tabular}

Berdasarkan tabel 5 di atas, dari lima puluh tiga responden diperoleh data sebagai berikut: satu orang (1.9\%) menyatakan tidak setuju bencana alam membuat semakin setia berdoa. Sikap responden ini didasari pada fakta dalam hidupnya yang sulit berdoa pasca bencana. Tiga orang (5.7\%) menyatakan ragu-ragu bencana alam membuat semakin setia berdoa. Sikap ragu-ragu dari responden disebabkan karena mereka tidak setiap hari berdoa kepada Tuhan. Apabila berdoa itu hanya karena sesuatu yang sudah menjadi rutinitas belaka, misalnya doa makan. Dua puluh tujuh orang $(50.9 \%)$ menyatakan setuju bencana alam membuat semakin setia berdoa. Dua puluh dua orang (41.5\%) menyatakan sangat setuju bencana alam membuat semakin setia berdoa. Responden yang menyatakan setuju dan sangat setuju disebakan karena kehidupan doa mereka yang berubah pasca bencana. Sebelum bencana kehidupan doa mereka tidak berjalan dengan baik dibandingkan setelah bencana. Data ini memberikan pemahaman bahwa mayoritas jemaat Gereja Bala Keselamatan Korps Jono Oge mayoritas melihat bencana alam membuat mereka semakin setia dalam kehidupan doanya. 
Tabel 6. Bencana Alam Membuat Saya Semakin Setia Membaca Firman Tuhan

Bencana alam membuat saya semakin seta membaca Firman Tuhan.

\begin{tabular}{|c|c|c|c|c|c|}
\hline & & Frequency & Percent & Valid Percent & $\begin{array}{c}\text { Cumulative } \\
\text { Percent }\end{array}$ \\
\hline \multirow[t]{4}{*}{ Valid } & Ragu-ragu & 9 & 17.0 & 17.0 & 17.0 \\
\hline & Setuju & 27 & 50.9 & 50.9 & 67.9 \\
\hline & Sangat Setuju & 17 & 32.1 & 32.1 & 100.0 \\
\hline & Total & 53 & 100.0 & 100.0 & \\
\hline
\end{tabular}

Berdasarkan tabel 6 di atas, dari lima puluh tiga responden diperoleh data sebagai berikut: Sembilan orang (17.0\%) menyatakan ragu-ragu bencana alam membuat semakin setia membaca Firman Tuhan. Sikap ragu-ragu dari responden ini disebabkan pada fakta bahwa mereka tidak setiap hari membaca Alkitab. Membaca Alkitab dilakukan ketika ibadah saja. Dua puluh tujuh orang (50.9\%) menyatakan setuju bencana alam membuat semakin setia membaca Firman Tuhan. Tujuh belas orang (32.1\%) sangat setuju menyatakan bencana alam membuat semakin setia membaca Firman Tuhan. Sikap responden yang setuju dan sangat setuju pasca bencana mereka semakin tekun membaca Alkitab karena dengan membaca Alkitab mereka mendapat kekuatan dan pengharapan di balik kesulitan mereka. Faktor hamba Tuhan yang terus memberikan dorongan untuk membaca dan hidup sesuai dengan kebenaran Alkitab menjadi pendorong utama mereka membaca Alkitab. Data ini memberikan pemahaman bahwa mayoritas jemaat Gereja Bala Keselamatan Korps Jono Oge mayoritas melihat bencana alam membuat mereka semakin setia dalam membaca Firman Tuhan.

Tabel 7. Bencana Alam Membuat Saya Semakin Tekun Beribadah

Bencana alam membuat saya semakin tekun beribadah.

\begin{tabular}{|ll|r|r|r|r|}
\hline & & & & \multicolumn{1}{c|}{$\begin{array}{c}\text { Cumulative } \\
\text { Percent }\end{array}$} \\
\hline Valid & Ragu-ragu & 3 & 5.7 & 5.7 & 5.7 \\
& Setuju & 27 & 50.9 & 50.9 & 56.6 \\
& Sangat Setuju & 23 & 43.4 & 43.4 & 100.0 \\
Total & 53 & 100.0 & 100.0 & \\
\hline
\end{tabular}

Berdasarkan tabel 7 di atas, dari lima puluh tiga responden diperoleh data sebagai berikut: tiga orang (5.7\%) menyatakan ragu-ragu bencana alam membuat semakin tekun beribadah. Sikap ini disebabkan responden pasca bencana tidak rutin untuk beribadah yang karena tempat mereka tinggal atau mengungsi jauh dari gereja sementara. Dua puluh tujuh orang (50.9\%) menyatakan setuju bencana alam membuat semakin tekun beribadah. Dua puluh tiga orang (43.4\%) menyatakan sangat setuju bencana alam membuat semakin tekun beribadah. Responden menyatakan setuju dan sangat setuju bencana membuat mereka semakin tekun 
beribadah karena memiliki banyak waktu untuk berkumpul dengan keluarga untuk berdoa bersama, beribadah dalam keluarga secara bersama-sama dan saling menguatkan. Model ibadah seperti ini dilakukan karena gereja jauh dari tempat tinggal mereka dan dalam keadaan rusak. Data ini memberikan pemahaman bahwa mayoritas jemaat Gereja Bala Keselamatan Korps Jono Oge mayoritas melihat bencana alam membuat mereka semakin tekun untuk beribadah, khususnya ibadah bersama dengan keluarga.

Tabel 8. Bencana Alam Membuat Saya Semakin Tekun Melayani

Bencana alam me mbuat saya semakin tekun melayani.

\begin{tabular}{|ll|r|r|r|r|}
\hline & & & & \multicolumn{2}{c|}{$\begin{array}{c}\text { Cumulative } \\
\text { Percent }\end{array}$} \\
\hline Valid & Sangat Tidak Setuju & 1 & 1.9 & 1.9 & 1.9 \\
& Tidak Setuju & 1 & 1.9 & 1.9 & 3.8 \\
& Ragu-ragu & 5 & 9.4 & 9.4 & 13.2 \\
Setuju & 28 & 52.8 & 52.8 & 66.0 \\
Sangat Setuju & 18 & 34.0 & 34.0 & 100.0 \\
Total & 53 & 100.0 & 100.0 & \\
\hline
\end{tabular}

Berdasarkan tabel 8 di atas, dari lima puluh tiga responden diperoleh data sebagai berikut: satu orang (1.9\%) menyatakan sangat tidak setuju bencana alam membuat semakin tekun melayani. Satu orang (1.9\%) menyatakan tidak setuju bencana alam membuat semakin tekun melayani. Sikap responden yang menyatakan sangat tidak setuju dan tidak setuju ini terjadi karena mereka memang sebelum bencana dan setelah bencana tidak terlibat dalam kegiatan pelayanan. Lima orang (9.4\%) menyatakan ragu-ragu bencana alam membuat semakin tekun melayani. Sikap responden ini terjadi karena mereka bukanlah orang yang mendapat tugas dalam pelayanan gereja, meskipun pasca bencana mereka mengikuti kegiatan-kegiatan gereja untuk membantu orang-orang yang membutuhkan. Dua puluh delapan orang (52.8\%) menyatakan setuju bencana alam membuat semakin tekun melayani. Delapan belas orang (34.0\%) menyatakan sangat setuju bencana alam membuat semakin tekun melayani. Responden menyatakan setuju dan sangat setuju bencana alam membuat mereka semakin tekun melayani karena mereka memang pada dasarnya adalah pelayan di gereja sehingga bencana alam membuat mereka semakin sadar akan penting pelayanan secara khusus terhadap pribadi-pribadi yang membutuhkan penguatan pasca bencana. Jenis pelayanan yang sering dilakukan adalah pastoral dengan cara mendoakan dan memberikan penguatan iman. Data ini memberikan pemahaman bahwa mayoritas jemaat Gereja Bala Keselamatan Korps Jono Oge mayoritas melihat bencana alam membuat mereka semakin tekun untuk melayani. 


\section{KESIMPULAN}

Berdasarkan data-data penelitian di atas, penulis melihat bahwa bencana alam 28 September 2018 yang terjadi di Sulawesi Tengah secara khusus di desa Jono Oge dan jemaat Gereja Bala Keselamatan Korps Jono Oge membawa dampak yang merusak dan merugikan dalam beberapa aspek kehidupan. Tetapi bila dilihat dari kehidupan iman atau spiritualitas jemaat membawa dampak yang positif. Artinya bencana alam berpengaruh baik terhadap spiritualitas atau kehidupan iman jemaat.

Hal tersebut dapat dilihat dari dua bagian penting dalam variabel-variabel penelitian. Pertama, sebagian besar jemaat mempunyai perspektif yang baik tentang bencana alam di mana sebagian besar mempunyai keyakinan bahwa bencana alam terjadi sebagai kejadian yang diizinkan oleh Tuhan. Sebagian besar jemaat memandang bahwa sebagai peringatan bagi kehidupan mereka dan juga sebagai ujian dan pencobaan iman.

Hal kedua, bencana alam berdampak dalam sebagian besar praktik kehidupan spiritual atau iman jemaat. Bagi sebagian besar jemaat, bencana alam membawa dampak bagi kehidupan rohani atau iman mereka yang bertumbuh, membuat mereka semakin setia berdoa dan membaca Firman Tuhan. Pada bagian yang lain, bencana membawa alam dampak kepada kesetiaan untuk beribadah dan melayani.

\section{KEPUSTAKAAN}

Badang Geologi, (2018). Di Balik Pesona Palu Bencana Melanda Geologi Menata, Bandung: Kementerian Energi dan Sumber Daya Mineral.

Bawamenewi, Wilson. (2020). Spiritualitas Seorang Pelayan Tuhan. ERESI: Jurnal Teologi dan Pendidikan Kristen, 1(1): 61-66. https://www.sttia-nisel.ac.id/ejournal/index.php/eresi/article/view/3.

Hermon, Dedi. (2018). Geografi Bencana Alam. Depok: Rajawali Pers.

Indiyanto, Agus dan Kuswanjono, Arqom. (2012). Agama, Budaya dan Bencana Kajian Integratif Ilmu, Agama, dan Budaya. Bandung: PT. Mizan Pustaka.

Khambali, I. (2017). Manajemen Penanggulangan Bencana. Yogyakarta: ANDI.

Lumintang, Stevri I. (2006). Theologia dan Misiologia Reformed. Batu: Departemen Literatur PPII.

Martini. (Desember 2011). Identifikasi Sumber Bencana Alam dan Upaya

Penanggulangannya di Sulawesi Tengah. Infrastruktur: Jurnal Teknik Sipil, 1(2),

96-102. http://jurnal.untad.ac.id/jurnal/index.php/JTSI/article/view/689.

McDermott, Gerald R. (2001). Mengenali 12 Tanda Kerohanian Sejati. Yogayakarta: Yayasan Andi.

Nego, Obet. (2019). Spiritualitas Calvin sebagai Spiritual Formation Mahasiswa Teologi. Manna Rafflesia, 6(1), 24-35. https://doi.org/10.38091/man_raf.v6i1.108.

Newman Jr, Barclay M. (1994). Kamus Yunani-Indonesia, Untuk Perjanjian Baru. Jakart: BPK Gunung Mulia. 
Prayudi, Sinatrya Diko, dkk. (November 2019). Pengaplikasian Olah Data Penginderaan Jauh, Pendekatan dan Permodelan Geologi dalam Kajian Bencana Likuifaksi di Wilayah Kabupaten Sigi, Provinsi Sulawesi Tengah, Prosiding TAU SNAR-TEK 2019 Seminar Nasional Rekayasa dan Teknologi.

Sareong, Irene Priskila dan Tri Supartini. (2020). Hubungan Komunikasi Interpersonal Guru dan Siswa Terhadap Keaktifan Belajar Siswa di SMA Kristen Pelita Kasih Makassar. Jurnal Ilmu Teologi dan Pendidikan Agama Kristen 1(1), 29-42. DOI: 10.25278/jitpk.v1i1.466.

Serli dan Hengki Wijaya. (2020). Metode Permainan Dalam Meningkatkan Pemahaman Firman Tuhan pada Remaja GKII Okahapi Sumba Timur. Jurnal Ilmu Teologi dan Pendidikan Agama Kristen 1(1), 17-28. DOI: 10.25278/jitpk.v1i1.459. Sudibyakto, A. (2011). Manajemen Bencana Indonesia Ke Mana? Yogyakarta: Gadja Mada University Press.

Utomo, Masitha Hanum dan Wenty Marina Minza. (2016). Perilaku Menolong Relawan Spontan Bencana Alam. Gadjah Mada Journal of Psychology, 2(1), 4859. DOI: 10.22146/gamajop.31871.

Wareza, Monica. Ini Korban Jiwa dan Kerugian dari 3 Bencana Alam RI di 2018. https://www.cnbcindonesia.com/news/20181225141956-4-47867/ini-korbanjiwa-dan-kerugian-dari-3-bencana-alam-ri-di-2018. 